\title{
When elective affinities foster Europeanization: How the EU active welfare state model and national policies for controlling the unemployed reinforced each other (1997-2005)
}

\begin{abstract}
This paper advocates the use of a Weberian framework in the analysis of the processes of Europeanization of public policies. It focuses on employment policies to explore the "elective affinities" between the European Employment Strategy launched in 1997 and the subsequent elaboration of national reforms reorganizing and strengthening monitoring, surveillance, and sanctions of the unemployed. From this perspective, Europeanization is defined as mutual reinforcement between European policy frames and national reforms than a top-down unilateral relationship of influence.
\end{abstract}

Keywords: Europeanization, active social state, control, unemployment, European Employment Strategy, France, international comparison, elective affinities, Weberian approach

JEL Classification Codes: I38, J68, N34

DOI: $10.33119 / \mathrm{KSzPP} / 2020.2 .1$

1 University of Strasbourg, Sciences Po, France, e-mail: vincent.dubois@misha.fr, https://orcid. org/0000-0003-2892-5120 
Kiedy powinowactwa $\mathrm{z}$ wyboru sprzyjają europeizacji. Jak wzajemnie wzmacniają się unijny model aktywnego państwa dobrobytu i krajowe polityki kontrolowania bezrobotnych w latach 1997-2005

\section{Streszczenie}

Niniejszy artykuł wykorzystuje ramy teoretyczne Maxa Webera do badania procesów europeizacji polityk publicznych. Skupia się na polityce zatrudnienia, by analizować „powinowactwa z wyboru" między Europejską Strategią Zatrudnienia zainicjowaną w 1997 r. a późniejszymi reformami krajowymi reorganizującymi i wzmacniającymi monitorowanie, sankcjonowanie i nadzór bezrobotnych. W tym ujęciu, europeizacja jest rozumiana raczej jako wzajemne wzmacnianie się polityki europejskiej i reform krajowych niż relacja oparta na jednostronnym, odgórnym oddziaływaniu.

Słowa kluczowe: europeizacja, aktywne państwo społeczne, kontrola, bezrobocie, europejska strategia zatrudnienia, Francja, porównania międzynarodowe, powinowactwa $\mathrm{z}$ wyboru, ujęcie Weberowskie

Kody klasyfikacji JEL: I38, J68, N34

The Europeanization of public policies has traditionally been analyzed from a top-down perspective as a vertical process. Radaelli's most cited definition itself remains focused on the influence of the European Union (EU) on domestic policies, even if the "construction" phase can involve the role played by the Member States in the definition of EU programs: "a process of (a) construction, (b) diffusion, and (c) institutionalization of formal and informal rules, procedures, policy paradigms, styles, 'ways of doing things' and shared beliefs and norms which are first defined and consolidated in the making of EU Public policy and politics and then incorporated in the logic of domestic discourses, political structures and public policies" (Radaelli, 2003: 30). Some authors have proposed more nuanced and complex views, for instance, by replacing the idea of a simple top-down influence with the notion of "diffusion" (Börzel, Risse, 2012). However, they most often retain a strictly causal reasoning, regarding domestic changes as the dependent variable that EU policies and processes, defined as independent variables, should explain. Such analyses have been most usefully complemented by approaches viewing national policy-makers not only as being influenced by the EU but as making strategic uses of the political and cognitive resources it provides, depending on domestic policy contexts (Graziano et al., 2011). Beyond their obvious differences, if not oppositions, scholars 
who analyze the Europeanization of public policies generally agree on its cognitive dimension, either as an explanatory factor or as a resource used by domestic actors.

Employment policies lend themselves to a reexamination of these questions. An EU employment policy was launched in the late 1990s under the name of the European Employment Strategy (EES) (Barbier, Sylla, 2004; De la Porte, Pochet, 2004; Conter, 2012). This has been a major domain for the implementation of the Open Method of Coordination, which has challenged the classic analyses of Europeanization processes (Kröger, 2009). The EES has promoted an "active social state" model, in line with orientations towards workfare promoted at the global level (Deacon, 2007). However, unlike in other policy sectors, EU decisions on employment and social inclusion are not directly binding upon Member States. National unemployment benefit systems remain very different in terms of institutional organization, funding, and benefit eligibility conditions. The provision of unemployment benefits and related practices, such as control over the unemployed, which is the focus of this paper, remain strictly national competences, not subject to direct EU interference. However, similar trends towards stricter requirements for the unemployed have been observed among EU Member States, which converge with the EES activation model. As we will see, these similarities include reforms in the bureaucratic organization and practices designed to monitor the unemployed and to sanction them in the event of an insufficient "active job search."

Why do different and independent national policies converge in tightening control and sanctions over the unemployed? How have these long-established bureaucratic practices acquired a new meaning and come to occupy a prominent place in unemployment policies? What role has the EU played in these changes? Lastly, how have these domestic reforms contributed to making the European model exist?

To answer these questions and to propose a new way to analyze Europeanization processes, I draw upon the notion of "elective affinities" as defined by Max Weber. In The Protestant Ethic and the Spirit of Capitalism Weber observes that capitalism established itself earlier and more firmly in regions where protestant ethic was influential (Weber, 2011). Far from causally explaining economic practices by religious beliefs, Weber shows the links of mutual reinforcement between these two distinct economic and religious phenomena, defining these two-way links as "elective affinities." Human beings need to make sense of what they do. The Protestant ethic proposes a belief system that can give meaning to economic capitalist practices. In this way, it contributes to their development. Conversely, the capitalist organization of socio-economic activities anchors the Protestant ethic in daily activities and in society in general.

Weber's analysis cannot be directly transposed to the relationship between EU programs and domestic policies. Yet, it may yield insights into the Europeanization 
processes under study here. The "active social state" model promoted at the EU level consists of a normative and cognitive framework that can give meaning to specific national reforms, even if they emerged because of domestic contextual factors. ${ }^{2}$ This model helps to legitimize them by offering a ready-made policy discourse based on expertise and international comparison. In this way, it contributes to their development, even in the absence of an explicit requirement to do so. Conversely, the adoptions of such reforms (here, the reinforcement of monitoring, surveillance, and sanctions of the unemployed in the name of "activation"), anchors the abstract "active social state" model in concrete policies and practices. National reforms reinforce the European model by contributing to making it real. I propose analyzing this mutual reinforcement as "elective affinities", which feed the three Europeanization processes of development of EU policies in new areas, of internalization and uses of European standards by national actors, and of converging trends in national public policies. This framework accounts for the cognitive dimension of Europeanization processes. However, instead of regarding ideas in themselves as explanatory factors, as it is more or less explicitly the case in most cognitive approaches to Europeanization, the "elective affinities" hypothesis focuses on their uses and explores the concrete conditions under which they come to play a role, in line with Weber's theory.

This paper illustrates this interpretive model by exploring the links between the "active social state" model promoted by the European Employment Strategy and the subsequent elaboration of national reforms consisting in a new and stricter organization of monitoring, surveillance, and sanctions of the unemployed. It addresses the period during which these links were most visible - the years that followed the adoption of the EES (1997-2005). Considering several EU Member States would have been of great interest but beyond the scope of a single article. In addition to the EU level, the empirical evidence focuses on France, in which workfare-oriented reforms, especially their coercive components, were introduced later than in other countries (such as the United Kingdom (UK) or Germany, for instance), making these changes and their relations to EU policies all the more visible. The study of the active social state model is based on policy documents from the Organisation for Economic Co-operation and Development (OECD), which has been influential in this domain, the European Commission, and the EES (guidelines, assessments, and national plans). The study of French reforms is mostly based on the qualitative analysis of official preparatory reports. These documents prove most useful to identify the role played by European references in the framing and legitimization rhetoric of these national reforms.

2 This indirectly echoes the analyses in terms of "uses of Europe" (Graziano et al., 2011). 
Part I retraces the major historical transformations that were conducive to reinforcing the role of control in unemployment policies. Both observable across the European continent, the gradual de-objectivation of unemployment, and the tipping of the socio-political balance of power to the detriment of the unemployed, go some way toward explaining the rise in stricter control policies. As a result, as shown in Part II, policy orientations mapped out at the supranational level that call for more stringent control have found a significant echo at the national level. Based on France as a case study, part III shows how a new control policy of the unemployed elaborated chiefly on national grounds uses EU-level trends as a justification, and reinforces them in the process.

\section{The changing status of the control of the unemployed}

Control of the unemployed can be defined as the coercive side of the monitoring and counseling of out-of-work individuals. It consists in bureaucratic practices of eligibility checks, making sure that those on unemployment benefits do not work or have hidden sources of income. Moreover, since "active job search" is a condition for being officially recognized as unemployed and a requirement for being granted unemployment benefits, control is mainly focused on efforts to find employment. Those whose behaviors are found to be fraudulent, improper, and more generally failing to conform with institutional expectations and requirements, face sanctions: provisional suppression of payments, deregistration, reduction or suspension of benefits for various durations, and prosecution in the case of fraud. These control practices date back to the "invention" of unemployment benefit provision as a category of public policy. In late nineteenth-century France, union welfare funds already subjected unemployed workers to close scrutiny in order to determine whether they "deserved" assistance and, if necessary, to filter out "parasites," either perceived as deviants (mostly alcoholics) or accused of not working hard enough to quickly regain a job (Salais et al., 1986; Daniel, Tuchszirer, 1999). During the 1930s in England, the means test, famously described by Orwell (Orwell, 1989), consisted in systematic surveillance of the living conditions of unemployment benefit recipients. Similar systems existed in many other European countries at this period.

Though not a new development by any means, these practices have gained unprecedented importance and significance across Europe since the mid-1990s - first in the UK with the 1995 Job Seeker's Act, and then for instance in Denmark, the Netherlands, Belgium, Germany, France and Poland (Sztandar-Sztanderska, 2016). While the "fake unemployed" had been routinely singled out for a long time in political and 
media debates and in everyday discourse about unemployment, it was only at that time that "benefit cheats" became an established subject of public controversy both in the media (with countless stories and reports on the subject) and in the political arena. Although the relevant organizations had long supervised unemployment benefit recipients in sometimes a directly coercive fashion, these practices had yet to be invested into the extent that they could become the backbone of a specific policy. They have been, by benefitting from intellectual investment in the production of legal, economic or managerial expertise; from technical investment in computer systems; from human investment in training investigators; from political and institutional investment in setting new standards; from organizational investments in the creation of new apparatuses and the redefinition of relationships between actors. While the unemployed were already sanctioned and struck off the roles following checks in an effort to make the unemployment figures artificially drop (Mathiot, 2001), the coercive decisions were not yet officially formalized as an instrument of these policies (even if just under the guise of "monitoring"). Control means more than just making sure that recipients' files comply with bureaucratic rules or that benefit payments are warranted. It is in line with the economic vulgate of "inactivity traps" according to which individual calculation and personal shortcomings are the main causes of unemployment (Dubois, 2014). From this perspective, checks and controls are conceived as means to influence the individual behaviors of the unemployed. They are supposed to redress them and put them in the right direction, that is to say back to work as quickly as possible.

The following section proposes some hypotheses on what is at stake in control practices and in the trends through which, at least since the end of the 1990s, control has come to play an unprecedented role in national unemployment policies. To analyze the convergence of these policies, the next section explores some aspects of the structural transformations of unemployment and of the policies towards the unemployed. These preliminary remarks at the national, social, and political level will help us to reflect on the reasons for such a convergence, and to assess the possible role played in this process by the diffusion of EU standards to the Member States and by the "learning" and "imitation" effects deriving from the intensification of interactions between national governments.

\section{The meaning(s) of control}

Six key points may give us a glimpse of the importance of control in unemployment policies and lay down the ground for historical and international comparison. This is a simplified presentation; obviously, one must keep in mind the differences 
between historical and national situations, especially between more or less insurance-based and assistance-based benefit systems.

1. Control is not limited to a formal procedure for checking the recipient's identity and the duration of their contribution. It also consists in ruling on individual employment situations. Before the question of compensation, the formal recognition of the status of unemployed is at stake. At the individual level, it actualizes the historically variable and highly complex social definition of the unemployed. Beyond their technical aspects, the evolutions and uncertainties of control thus reflect those of the definition of the unemployed, a question that has been nagging since the beginning of the history of unemployment.

2. Therefore, control can be viewed as a "rite of institution," that is, a relationship of domination in which the state exerts its power of nomination (Bourdieu, 2014). State agents mandated by their institutions are endowed with the power to grant (or deny) the status of "unemployed," authorizing individuals to define themselves as such. In this regard, mechanisms of control contribute to the practical implementation of "the institution of the unemployed" (Salais et al., 1986), i.e., the application of an abstract concept to concrete individuals who internalize it (they think of themselves as "unemployed") and externalize its key features (they behave as such).

3. In this way, we can see how control practices orient individual behaviors, especially as they consist in face-to-face relations in which institutional injunctions are expressed (on such processes, see Dubois, 2019). More importantly, the official definition of unemployment actualized in control procedures conveys institutionalized social expectations towards the unemployed, and is embedded in a balance of power that drives the unemployed to fulfil them. Control and the sanctions that may follow are, in this sense, instruments of the "government of conducts" (Foucault, 2002) of the unemployed.

4. Conversely, since control is most often directly related to the provision of public assistance to the unemployed in the form of financial compensation or job placement assistance, it refers to the obligations of society towards the unemployed. As the meeting point between "rights and duties," it touches on a moral issue in terms of the obligations of the unemployed, but also in terms of the legitimate reasons for a community to assist them: to promote mobility, to help the disadvantaged, to facilitate the search for employment, to encourage or force individuals to be "active" again, etc. These value systems are, in fact, debated, (re)asserted, objectivated, or at least implicitly enshrined in control policies, even in their seemingly most technical aspects.

5. In a context of mass unemployment, control relates to pragmatic issues that are much more immediately perceptible. Control impacts the official statistics on unemployment because it operationalizes the distinction between actual and "fake" 
unemployed people; those officially recognized as such are listed, while the others are struck off; those who do not meet institutional expectations are more or less severely excluded. As the main statistics on the subject are provided by the main state bodies that deal with unemployment, they are particularly likely to be affected by the evolutions of administrative control practices. The control of the unemployed is thus a factor of the official unemployment rate, which attracts considerable public scrutiny.

6. Finally, the varying degrees of severity of control have significant financial implications not only for those subjected to checks but also for the management of benefit funds. Recipients who are deregistered and sanctioned lose their benefits, at least partly or provisionally. This is a particularly sensitive issue at times when the unemployment insurance deficit reaches high levels. Managerial approaches in which control and sanctions are seen as ways of cutting benefit expenditure, therefore, add up to the interlinked moral arguments and logics (reminding the unemployed of their duties, punishing the "undeserving" to help the "deserving" better), pragmatic objectives (incentivizing return to work) and political rationales (maintaining citizens' approval of the benefits system).

\section{Historical variations}

As control of the unemployed stands at the intersection of multiple key issues, its intensity and forms vary according to changes in unemployment policies. Three main phases can be identified:

1. The question of control was particularly important from the late nineteenth century to the aftermath of the Second World War, a period over which the "unemployed" as a category was being defined and the unemployment benefit system was gradually set up. Control was an element in the specification of the definition of unemployment, and part of the non-linear process of objectivation of this category (Salais et al., 1986: 115; Topalov, 1994). It was also a major focus in the debates on the elaboration of assistance funds for the unemployed. The fear of fraud, a consequence of the difficulty to identify those who "really" are unemployed, played a structuring role in determining possible responses to unemployment: forced labor, assistance in kind and in cash, provision of state-funded or insurance-based benefits (Guitton, 1994). During this first long period of time, the issue of fraud was particularly pressing. In the 1930s, for instance, the rising number of unemployed persons was seen as a "threat" to be averted.

2. On the other hand, improvements on the labor market lead not only to a reduction in unemployment but also to the stabilization of its definition and forms of compensation. This was roughly the case from the post-war period to the mid-1970s. 
Unemployment was not touted as a major issue, and the provision of benefits was generally seen as a condition for the mobility of workers. Additionally, the objective situations of the unemployed more easily fitted the definition of "workers involuntarily and temporarily deprived of work": categorizing them was less problematic, and they were less readily suspected of fraud.

3. Control gradually resurfaced as a sensitive issue, and a subject of debate as mass unemployment plateaued, starting in the mid-1970s. Since then, there has been a growing pressure to perform more stringent checks, as a result of the increasingly blurred boundaries between employment and unemployment, of transformations in the rationales behind unemployment policies and of changes in power relations affecting the definition of these policies. The combined effect of these three main distinct yet interdependent trends explains how the control of the unemployed, once merely seen as a technical or secondary question, became such an important issue in unemployment policies. Such a combination has been particularly marked from the early 1990s onwards. These trends have been observed in many European countries, which goes some way toward accounting for the convergence in national unemployment policies. However, it is also worth noting that the variations in the timing and intensity of these trends help explain differences between national policies.

Firstly, the situation on the job market has worsened, and the range of possible types of employment has widened, with the rise of temporary and part-time work and of short-term contracts. Therefore, the situations of an increasing number of workers fall somewhere between employment and unemployment. The concept of employment, which forms the basis for defining the "unemployed" category, has become increasingly hazy if not "dislocated" (Demazière, 2003: 77; Maruani, 2002: 31). In addition to the objective transformations of employment that lead to the disaggregation of unemployment, ${ }^{3}$ some scholarly representations of labor economics that "deconstruct" unemployment have become increasingly influential (Gautié, 2002). The success of concepts such as "unemployability," disseminated and promoted internationally as the founding principle of employment policies and, last but not least, the increasing number of types of unemployment benefits, have been part of this process. The control of the unemployed has been increasingly perceived as "necessary" in large part because the definition of what being unemployed really means has been more and more uncertain.

3 Here are some examples in France: the separation of insurance and assistance schemes in 1982, the distinction between insurance and solidarity schemes in 1984, the introduction of the RMI (minimum benefit) in 1988 - which quickly became an alternative form of provision of unemployment benefits - the increase in the number of categories of jobseekers (from five to eight) in May 1994. 
Secondly, the agenda-setting of control can be understood only in the light of the transformations in the rationales guiding unemployment policies. Two key transformations that have been fairly widespread in Europe in the last decades deserve to be mentioned. The imperative of public expenditure control has resulted in the nearly continuous decrease in the provision of unemployment benefits, a trend that began in the early 1980s and intensified over the following decade (Barbier, Théret, 2004; Daniel, Tuchszirer, 1999). The tightened conditions for being eligible to benefits, the greater demands imposed on recipients, and accordingly, the more stringent checks on their situations and practices have been by-products of the promotion of cost containment as a cornerstone of social and employment policies. The restriction of unemployment coverage is also linked to a shift in unemployment policy toward encouraging return to work. From this perspective, the stricter checks and the decrease in benefit payouts have been perceived as "incentivizing" measures, or in other words, means to curb the impact of the supposedly "disincentivizing" effects of "overgenerous" benefit provision (DARES, 2003). While there have been other developments in unemployment policies, expenditure control, and "activation" policies have been salient features (Lødemel, Moreira, 2014). By incentivizing public expenditure cuts and promoting normative frameworks (the "active welfare state," with closer ties between social protection and work and more emphasis on commitment to return to work), European integration has undoubtedly contributed to such trends and, therefore, (indirectly) to the promotion of control. Yet, other factors also require consideration.

Indeed, changes in power relations at the national level are the third trend, which has had a much more direct impact. National socio-political configurations have encouraged greater rigor in the government of the unemployed. In government elites, advocates of social orientations have lost ground to the neoliberals, critical of the "adverse effects" of the welfare state. The motto coined by Margaret Thatcher in the late 1970s, according to which welfare was a solution, but it is now a problem, once was the signature of ultraliberals. It has gained influence, and the idea that traditional welfare has to be reformed if not always reduced has percolated across the political spectrum, as shown by the evolution of socialist and social-democrat parties such as New Labour in the UK, the Social Democratic Party under Schroeder in Germany, and, to a lesser extent, the French Socialist Party. A similar trend can be observed at the top levels of the state bureaucracy, with the rise of "managers," including in sectors such as social and employment policies previously preserved from neo-managerial orientations (see Hassenteufel et al., 1999; Mathiot, 2001 for the French case). Lastly, in the negotiations between "social partners," employer organizations, generally eager to save money on unemployment and social benefits, 
have gradually prevailed over workers' unions, which, incidentally, have historically shown little commitment to the cause of the unemployed.

All of the above factors have encouraged the diffusion of negative representations of the unemployed and the implementation of policies that lower benefits and impose more constraints. The tightening of control is the direct result of such political representations and orientations.

This trend does not equal a return to the time when the institutional monitoring of the situations and behaviors of the would-be unemployed persons made sense within the broader context of the gradual stabilization of the "unemployed" category and of the benefits scheme. The salience of the issue of control from the late twentieth century onwards might arguably reflect a reverse process. Indeed, while the importance granted to control during the first two-thirds of the twentieth century was part of the process of objectivation of unemployment as a collective category and of the implementation of measures for providing assistance to the unemployed, it is now a reflection of the de-objectivation of the "unemployed" category and of the reassessment of the unemployment benefit system.

\section{The elective affinities between the "active social state" and control policies}

Having these historical landmarks in mind, we can better grasp the impact of internationally disseminated employment policy models, here more precisely in the EU. In the case in point, this impact cannot be reduced to the transposition of normative frames formed at the supranational level into national policies. These norms are not directly binding and include no explicit prescriptions regarding control. Max Weber's concept of "elective affinity" (Weber, 2011) is arguably better suited to shedding light on processes through which two systems of meaning and practices meet, converge and reinforce each other: here, the active social state model and policies promoting control and sanctions over the unemployed.

The model of the "active social state" has been widely promoted by international organizations like the OECD, and held as a reference for the harmonization of EU social and employment policies, through channels such as the European Employment Strategy (EES) launched in 1997. Several features of this model make it a political and intellectual breeding ground for setting up reinforced control apparatuses. National policies should not be considered as mere applications of this model or understood as the effects of its diffusion. They are, in some cases, inspired by it, but they have their own logic, and some, like in the UK or Belgium, have preceded its 
adoption by the EU. Nevertheless, the active social state model provides elements letting national policies refer to objectives considered as desirable, giving meaning to the practices these objectives entail, and legitimizing controversial orientations. Conducting checks on the unemployed is ostensibly no longer about "hunting down the poor," but about fighting the "unwanted effects" of the "traditional welfare state" and working for the "return to employment" by "supporting the unemployed."

\section{An international model for social and employment policies}

The principles underpinning this model, stated in numerous reports, resolutions, and other institutional documents, revolve around three main points. The first consists in making work more attractive. "Making work pay" has been one of the OECD's mottos since the mid-1980s; the theme is regularly addressed in the organization's yearly Employment Outlook publication: "Activity for all in tomorrow's society" (1987); "Steps towards an active society" (1988); "The path to full employment: structural adjustment for an active society" (1989); "Rewarding work" (2000) (see Mc Bride, Williams, 2001). The OECD expertise has been influential in the framing of EU labor and welfare policies (Dostal, 2004). Similar leitmotivs are found in European Commission documents, particularly since the creation of the European Employment Strategy (EES) in 1997. ${ }^{5}$ While the slogan "making work pay" is intended "to strengthen the incentives to work," it also reduces the attractiveness of welfare and social protection systems, with tougher eligibility criteria, shorter compensation periods, increased demands on recipients, tightened checks - these practical "solutions" are logical extensions of the incentive to "make work pay."

The flip side of this trend is the denunciation of so-called passive expenditure, a cornerstone in the relationships between labor market policies and social policies (OECD, 1991, 1992, 1993, 1994, 1995). To mention just one example among many, a Communication from the European Commission dated July 1999, which reappeared in the Conclusions of the December 1999 Council, argued that "the new labour market called for more than simply providing traditional forms of protection like the guarantee of a replacement income" and drew attention to the "need for a new balance between flexibility and security, as well as between rights and responsibilities." 6 The opponents of the "passive social state" are eager to denounce the benefits system as lax and to stigmatize its improper uses, which contributes to making the reinforced

4 Expressions in parentheses are those commonly used in the public debate and in policy discourse. For an overview, see (Barbier, Sylla, 2004; de la Porte, Pochet, 2004; Conter, 2015).

6 Social Protection Committee, Key Issues on Social Protection and Employment, 1999 (Revised Version - June 2003). 
checks even more valuable. Using a more explicit phrasing, a Communication from the European Commission dated December 2003 singled out unemployment insurance benefits as one of the "obstacles to integration on the labour market", arguing that "unemployment benefits can create counter-incentives to work since they are paid over a long period and are neither monitored nor controlled adequately through clear requirements in terms of active job search, professional tests and participation in active measurements on the labour market."'

The discourse on the dead-end in which the "passive welfare state" allegedly finds itself comes with a utilitarian conception of the behavior of welfare recipients. As it is assumed that the unemployed are rational actors who calculate their utility on the job market, "combating inactivity traps" is a "labor market mobilization challenge" (OECD, 2003). Joint action is encouraged to reform the allocation of benefits, the length of compensation periods, the eligibility conditions and, last but not least, the conduct of increasingly stringent checks, since, as the unemployed are considered as individuals seeking to maximize their interest, they are accordingly viewed as potential "profiteers." These institutional prescriptions ${ }^{8}$ echo a number of economic studies that praise the virtues of control and penalties as incentives for return to work (see, for instance, Abbring et al., 2005).

These three main principles are actively disseminated across the world. They serve as the basis for discussing employment policies in the EU, making up a set of linked proposals that together define a genuine model, wherein the conduct of stricter checks on the unemployed is considered as a desirable practice for national employment policy.

\section{The ambiguous role of the European Employment Strategy}

The European Employment Strategy (EES) is undoubtedly one of the main vehicles for the convergence between this European model and national policymaking. Many studies have shed light on the distinctive features of the Europeanization processes of national policies resulting from the Open Method of Coordination (OMC), of which the EES has been the first major application (de la Porte, Pochet, 2004; Conter, 2015). This strategy is based on benchmarking practices requiring the definition

\footnotetext{
7 Communication from the Commission to the Council, the European Parliament, to the European Economic and Social Committee and the Committee of the Regions, Modernising social protection for more quality jobs: A general strategy for making work pay, 2003.

8 Additional research would be necessary to identify differences over time and nuances in terms of approach - the OECD and the European Commission also have their own agendas - and to conduct a finer analysis of the systems of representations and rationales at work.
} 
of shared indicators for identifying "good practices" (Bruno, Didier, 2013). In turn, their harmonization lays the ground for "guidelines" serving as references for the "national employment action plans" drawn up by Member States and subsequently, synthesized by the European Commission and the Commissioner for Employment and Social Affairs. This strategy does not fit the usual patterns of "vertical" vs. "horizontal" Europeanization processes. In the following, I attempt to show how, in the particular case of control of the unemployed, a general orientation developed, defined through multiple European exchanges and specific reform projects, strongly informed by national rationales.

The EES has undeniably been an important vector of Europeanization, given that it has placed employment policies in the European framework, while they were previously traditionally elaborated and debated at the national level. This has provided both an opportunity to define joint orientations (guidelines) and, in the spirit of the $\mathrm{OMC}$, to conduct comparisons and discussions between Member States. Thus, the National Action Plans for Employment (NAPE, later known as NAPs) drawn up every year, constituted both reference documents at the national level and crucial elements in the linkage between national policies and European orientations.

The conduct of checks on job seekers is not explicitly mentioned in the EES guidelines or in the recommendations addressed by the Council and the Commission to the Member States. All parties involved, EU officials, and Member States' representatives who put pressure on each other (Barbier, Sylla, 2001: 93), have determined principles whose application, left to the responsibility of the Member States, have led to the establishment of national control policies. This also works the other way around. While national rationales for the elaboration of unemployment policies suggest new control policies, the latter find meaning in the principles outlined by the European recommendations and guidelines. The "elective affinities" hypothesis accounts for this relationship of mutual reinforcement, rather than causation.

France of the early 2000s is the case in point. Recommendation No. 2 of the 2002 NAP calls for "building on recent tax-benefit reforms, continuing implementing and monitoring the impact of policy measures designed to encourage workers to seek and remain in work, particularly measures with an effect on low-skilled and lowpaid workers" - in other words, combating "inactivity traps," specifically by reforming the benefits system. The French response follows:

"The effective elimination of factors contributing to the reluctance to resume employment for economic reasons has been a constant concern during recent years (...). The incentive to go back to work or continue working, particularly in the case of low-paid jobs, is being reinforced by the combination of several mechanisms that help to reduce 'unemployment traps' and maximise income when individuals find 
a job again. These measures are complementary to, and inseparable from, the more quality-oriented return-to-employment support programmes" (NAP, 2002).

There are, however, two sides to these "quality-oriented support programs": "positive incentives" and assistance to return to work, and "negative incentives" and increasing control of the effectiveness of efforts to regain work. Recommendation No. 3 precisely suggests "pursuing implementation of personalized and early intervention schemes for the unemployed; examining the effectiveness of and report on the implementation of the Personalised Action Plans for a New Start initiative." The French government's 2003 report directly adopts this approach by introducing a reform of the public employment service; the 2004 document announces that an updated system of checks and penalties has been put in place.

These measures, which had been envisioned for a long time in France and ardently championed by the national employers' organization Mouvement des entreprises de France (French Business Movement, MEDEF), led to the creation of the Plan d'aide au retour à l'emploi (Return-to-work Assistance Action Plan, PARE) as part of the unemployment insurance agreement that came into force on 1 July 2001. The stricter control of the unemployed demanded by the employers' organization with support from a major workers' trade union (Confédération française du travail, CFDT) was originally promoted in return of the end to the gradual decrease in benefit payouts: the unemployed would be better compensated on the condition that their "efforts" were more closely monitored. This proposal ended up being one of the major stumbling blocks in the ministerial approval process and ultimately had to be dropped due to the opposition from then Minister of Labor Martine Aubry (Dubois, 2006). A few months later, a number of projects emerged in view of "increasing the effectiveness of control" and "supporting" the unemployed in the process of returning to work, and were put in practice with the preparation of the Social Cohesion Plan in 2004. This was arguably not so much an effect of the diffusion of European principles as the result of a shift in the balance of power at the national level, making the implementation of previously shelved reforms easier.

Similar observations can be made concerning the redefinition of "suitable employment," a concept coined by the International Labor Organization in 1948, that is both uncertain and strategic in terms of employment policy. While the concept has elicited variable national definitions (Freyssinet, 2000), its wide and extensive application has long been demanded by employers' organizations (e.g., MEDEF in France), in accordance with their wishes for greater European harmonization. The EES has used the most flexible national legislations as blueprints, hence those most restrictive for the unemployed. As the notion of "suitable employment" is the basis for the definition of "suitable job offers," it indeed serves as the yardstick to determine what 
constitutes a legitimate refusal to work. Lower pay than in the previous position, no match between the job seeker's qualifications and the requirements or a long distance between the workplace and place of residence are generally considered as legitimate motives for turning down a job offer. Broadening the criteria means increasing opportunities to enforce penalties on the unemployed, whose freedom of choice is restricted. This means that control is no longer used for verification purposes only; it has become an instrument for imposing pressure on the unemployed to accept potentially low-paid, precarious jobs, force them into geographic or professional mobility.

\section{"Others have done it": legitimization through Europeanization}

Having presented the active social state model and explored its paths of dissemination through the European Employment Strategy, I reconsider in this section the hypothesis of elective affinities between this model and stricter control of the unemployed, this time by focusing on the elaboration and legitimization of the national policies that organize this control. The case of France shows that these policymaking and legitimization processes, although they have remained shaped by national rationales, draw on European references, both as illustrations and examples to follow, that help in presenting control as a defining feature of modern employment policies, and justifying reforms portrayed as commonsense, necessary steps.

In France, these orientations have been given a concrete form in the provisions of the 2005 "Social Cohesion Plan": clarification and increase in the requirements for unemployment benefits recipients, expansion of the possibilities for deregistration, gradation of sanctions, reform of the organization of controls between the various employment administrations, ${ }^{9}$ easier access to the individual data required for controls. ${ }^{10}$ Additionally, a monthly follow-up of job seekers by the employment agency (ANPE) was introduced, and the organization in charge of benefit payments

9 Namely, the Directions départementales du travail de l'emploi (local administrations of the national Ministry of Labor, in charge of verifying active job search), the Agence nationale pour l'emploi (national employment agency with local antennas, in charge of job counseling and placement), who controlled the unemployed in a less direct and official way and could deregister them, and the organization responsible for the payment of benefits, who could recalculate and suspend them, UNEDIC at the national level, ASSEDIC at the local level.

10 See the Loi de programmation no. 2005-32 of 18 January 2005 on social cohesion, especially Articles 11 and 12 of Section IV on "return to employment assistance for unemployed workers"; decrees no. 2005-915 of 2 August 2005 and no. 2005-1624 of 22 December 2005 on the monitoring of job seekers; and the Ministry of Employment circular dated 19 September 2005. 
(UNEDIC) took measures to combat fraud and, more broadly speaking, track down the unemployed thought to be insufficiently active in their job search (Dubois, 2006).

It is beyond the purview of this paper to map out the complex set of actors, relationships, negotiations, and practices that have shaped these new control policies. The analysis is, therefore, based on a particularly important element in their genesis: the preparatory reports. These documents indeed constitute a crucial stage in the officialization of "public problems" and their constructions (Lahire, 1999: 81-99), and serve as a tool for the formatting and systemization, if not the definition of the "official line" (Lebaron, 2001). In this sense, they constitute relevant material for understanding the logic underpinning the elaboration and legitimization of new policies. In the case at hand, these reports are all the more valuable as they play a crucial role in the linkage between European references and national policies.

\section{The unprecedented salience of control}

The official reports published in France have been both manifestations and vehicles of a newfound public interest in the control of the unemployed. The first traces of political and administrative investment in control date back to the early 1990s. This interest subsequently grew. Four main reports were published in 2004 alone, in contrast to the virtual absence of comparable documents in previous years. This many-sided question can indeed be approached from various angles, from the relationships between the different public service departments in charge of employment, to the official unemployment statistics, the causes of unemployment, or the behavior of job seekers. All these questions have been concerns for some time but had not previously been subjected to such a unified and intense treatment.

The annual report by the Court of Auditors for the year 2003 published in mid-January 2004 included a chapter on conducting checks on job seekers (Cour des comptes, 2004). It was shortly followed by a report commissioned in anticipation of the Mobilization for Employment Act, which became a component of the 2005 Social Cohesion Plan published in February (Marimbert, 2004). This document advocating for closer collaboration between public administrations in charge of employment gave a very important place to the organization of the monitoring and sanctions of the unemployed. A few months later, in October 2004, a report by a committee chaired by governor of the Bank of France and former Managing Director of the International Monetary Fund Michel Camdessus tackled the same issue within a much broader discussion of "France's major economic choices" (Camdessus, 2004). In December of the same year, two economists submitted their report commissioned by both the ministers of Economy and Employment on "occupational social security." They 
called for an increase in the personalized monitoring and control of the unemployed, in terms roughly similar to those used in the Marimbert Report (Cahuc, Kramartz, 2004: 45-47, 61-66).

Although it is difficult to assess the actual impact of such reports - which cannot be reduced to the question of whether their recommendations are directly implemented or not - it is clear that this wealth of publications over such a short timespan contributed to making control a subject of public attention. These reports made positive references to each other and generally converged on the need to reconsider the place of control and make it more effective in employment policies.

The first two reports were made public in an interval of two weeks. Due in part to the controversial nature of their content, they received wide media coverage and public discussion, not so much providing answers to a pre-existing debate, as encouraging stances on the reinforcement of control, now held as an important matter of employment policy. In that sense, they played an important part in shaping and legitimizing this orientation. The Marimbert Report, which was explicitly intended to lay down the groundwork for the reform of employment policy and of the public employment service, provided so-called observations (on the ineffectiveness of the existing control system), practical arguments and orientations (such as the gradual sanctions system) that helped in elaborating future measures. The report by the Court of Auditors played a twofold role, through the publicity it received, and by placing control on the agenda of the organizations concerned. ${ }^{11}$

\section{Legitimization through Europeanization}

These reports share a great concern with the "European dimension" - hardly an original preoccupation by then, but one that, in this instance, served to support an orientation that largely favored increased checks and penalties. Upon closer examination, it appears that references to EU employment policies are rather vague, which is arguably not very surprising given the content of these policies. European and international references were much more prominent in the elaboration of the reports. The team involved in drafting the Camdessus Report was, for instance, assisted by a "group of European experts," most of whom were Commission officials. The preparation of the Marimbert Report was an opportunity for meetings with European figures, including four European civil servants from the Directorate-General for Employment and no fewer than ten experts and representatives of Dutch organizations. The latter was a very deliberate choice, since the Netherlands were one of the

11 UNEDIC, ANPE, and the Ministry of Employment. On these organizations, see above, note 8. 
first countries to privatize job placement and increase control of the unemployed. The report also draws heavily on OECD data.

Arguably, the European dimension is most clearly indicated by the references to "experiences" in other EU countries. ${ }^{12}$ As most other sectors in recent years, employment policies have been the subject of double comparative obviousness. Firstly, the reference to the practices of "our European neighbors" has become self-evident. For the EU Member States involved in cooperation and benchmarking practices, this has indeed been promoted as the specific form of international comparison, which has more generally become a requirement of policymaking (Page and Mark-Lawson, 2007). Secondly, this spontaneously comparative approach is itself to present specific policy orientations as obvious, inevitable ones. Although they are most often based on very incomplete knowledge of other countries' situations and make partial use of information and of "lessons" drawn from this information, European comparisons are used to present new policy orientations as if they were undebatable choices.

In this way, the Marimbert Report highlights the "best practices" implemented in Britain, Italy, the Netherlands, or Sweden and the "successes" they have enabled to achieve. An appendix presents "foreign experiences" aimed at proving that countries which have already taken steps to enforce stricter requirements on the unemployed have improved the situation of employment in their job markets thanks to these measures. The Camdessus Report is particularly edifying on that level. In the chapter tellingly entitled "Others have done it," public policies implemented by various countries are touted as "good practices," deserving to be followed in France. Examples include Denmark, where it is claimed positive results have been achieved thanks to "more restrictive conditions for eligibility to the unemployment insurance scheme," shorter compensation periods and the obligation to enroll in returnto-work programs at an earlier stage (p. 45). In the discussion of the "British model" is also discussed, the decrease in unemployment in the UK is presented as a fact, although it is disputable. ${ }^{13}$ Moreover, the "British success" is attributed to "a strong policy choice by the successive governments, who emphasized the irreplaceable role of work" (p. 46). The report points out that this has resulted in major transformations in the public employment service: "the 1996 reform of jobseekers' allowances led

12 In contrast, very little mention is made of the United States or Canada. On the other hand, a few references are made to Australia, where one of the earliest mechanisms for "profiling" the unemployed was invented by the Ingeus company - and later imported into France as part of the measures to "support" jobseekers.

13 The report does not relate this observation to other parameters such as the decrease in the size of the working population - which expanded in France over the same period - or even the high increase in part-time employment. It is also based on dubious data. Increasingly broad criteria were used to strike off job seekers from the unemployment register, which resulted in their exclusion from statistics. 
to tightening control of the effectiveness of job search after six months. The provision of allowances is conditional on the job search and on the household's resources. The allowances tend to decrease as the recipient's income increases. Rights and obligations in terms of training and job placement follow various stages, matching objective criteria that vary with the duration of the unemployment period" (p. 46). These are precisely the reforms that the report urges the French government to consider.

Without going into detail on an argument that often combines very different registers (technical and moral, economic expertise and the common sense, legal issues and broad societal trends), it is worth noting that these European examples are used as a basis to recycle the slogans of the active social state coined at the international and European level, and disseminated as policy norms through the European Employment Strategy and its Open Method of Coordination. Preferring work over entitlement, combating obstacles to integration on the job market, making work pay - these references are both hazy and hard to argue with in principle. They have, nevertheless, enabled those using them to conceptualize stricter control of the unemployed and to present it as a desirable option.

Now we have a better understanding of the reasons for the trend towards tighter control of the unemployed and of the logic behind its generalization across Europe. Firstly, widely shared structural transformations have led to converging evolutions. The de-objectivation of the category of "unemployed" in the context of a protracted economic crisis has led to a more acute questioning of who is "truly unemployed" and who is not, and to the strengthening of the mechanisms for verifying this status. The dissemination of neoliberalism across the political spectrum and the consequent decline of welfare advocates, the rise of managerialism in welfare and employment organizations and the increasing role of employers' organizations to the detriment of workers' unions in the negotiations of unemployment benefits schemes have established national, socio-political configurations that are ill-suited to the defense of the cause of the unemployed. New financial constraints weighing on employment policy have been conducive to restricting the provision of unemployment benefits. This has been all the more the case as these benefits have been increasingly perceived as "disincentivizing to work," and therefore, part of the causes of unemployment. Restrictions and closer monitoring of job searches have become tools for "back to work" policies, and most European countries have adopted policies imposing more stringent demands on the unemployed, which include stricter procedures for checks and sanctions. 
Secondly, these policies were able to rely on the elaboration and diffusion of a so-called employment policy model at the European level, known as the Active Social State. The channels used for the promotion of this model - benchmarking and "coordination" - and the lack of explicit recommendations on control at the EU level suggest that the converging orientations of national governments cannot be explained by the EU's unilateral influence. The relationship between this European orientation and national control policies appear to owe more to "elective affinities," whereby two distinctive political objects meet and reinforce each other. As the new national control policies find in the European model resources that give them meaning and legitimacy, this model, in turn, becomes more than an abstract slogan.

Thirdly, the analysis of the French case clearly exemplifies that control policies can be tightened following the diffusion of a comparative discourse presented as self-evident. The purported inevitability of comparative references, the modalities of their uses influenced by benchmarking practices, and their orientations towards stricter workfare, clearly evidence the role played by the EU Employment Strategy, through both its procedures (Open Method of Cooperation) and the policy norms it conveys.

Beyond the specific case of employment policies, this case study illustrates the contribution of the "elective affinities" hypothesis to the analysis of Europeanization processes. Rather than considering these processes from a causal and sometimes univocal perspective (as in top-down cognitive approaches), or seeing them as mere policy transfers from one state to another, this hypothesis proposes a new way to account for the dynamic articulation between the different levels of policymaking. Thus, it was possible to show how the relatively autonomous area of EU policymaking could influence national reforms and organize their mutual comparison and learning, how these reforms could make strategic use of both EU standards and comparisons between the Member States, and how this contributed to the very existence of EU policies.

The "elective affinities" hypothesis also sheds a new light on the role of cognitive frames on policymaking. These frames do matter, as resources for both giving meaning to policy practices and justifying policy choices. However, they do not matter by themselves, but through their concrete uses by national actors, determined by national socio-political contexts and following national strategies. Moreover, they matter all the more as they fit into these contexts and strategies. Far from an idealistic approach assuming the intrinsic "power of ideas," this follows Weber's approach investigating the conditions under which "ideas can become effective forces in history" (Weber, 2011). 


\section{References}

Abbring, J.H. et al. (2005). The effect of unemployment insurance sanctions on the transition rate from unemployment to employment. Economic Journal, 115(505): 602-630.

Barbier, J.-C., Sylla, N.S. (2001). Stratégie européenne pour l'emploi: les représentations des acteurs en France. Paris: CEE- DARES.

Barbier, J.-C., Sylla, N.S. (2004). La stratégie européenne pour l'emploi: genèse, coordination communautaire et diversité nationale. Paris, CEE-DARES.

Barbier, J.-C., Théret, B. (2004). Le nouveau système français de protection sociale. Paris: La Découverte.

Börzel, T.A., Risse, T. (2012). From Europeanisation to Diffusion: Introduction. West European Politics 35(1): 1-19.

Bourdieu, P. (2014). On the State. Oxford: Polity Press.

Bruno, I., Didier, E. (2013). Benchmarking: L'État Sous Pression Statistique. Paris: Éditions La Découverte.

Cahuc, P., Kramarz, F. (2004). De la précarité à la mobilité: vers une sécurité sociale professionnelle. Paris: Rapport au ministre de l'Économie, des finances et de l'industrie et au ministre de l'Emploi, du travail et de la cohésion sociale.

Camdessus, M. (2004), Le sursaut. Vers une nouvelle croissance pour la France. Paris: La Documentation française.

Deacon, B. (2007). Global Social Policy \& Governance. Los Angeles: SAGE Publishing.

Conter, B. (2012). La stratégie européenne pour l'emploi: de l'enthousiasme à l'effacement. Bruxelles: CRISP.

Cour des comptes (2004). Le contrôle de la recherche d'emploi. In: Rapport public 2003. Paris: La Documentation française: 35-56.

Daniel, C., Tuchszirer, C. (1999). L'État face aux chômeurs. L'indemnisation du chômage de 1884 à nos jours. Paris: Flammarion.

DARES (2003). Les politiques de l'emploi et du marché du travail. Paris: La Découverte.

De la Porte, C., Pochet, P. (2004). The European Employment Strategy: existing research and remaining questions. Journal of European Social Policy, 14(1): 71-78.

Demazière, D. (2003), Le chômage. Comment peut-on être chômeur? Paris: Belin.

Dostal, J.M. (2004). Campaigning on Expertise: How the OECD Framed EU Welfare and Labour Market Policies - and Why Success Could Trigger Failure. Journal of European Public Policy, 11(3): 440-460.

Dubois, V. (2006). Le contrôle des chômeurs. GSPE-DARES, Ministère du Travail.

Dubois, V. (2014). The Economic Vulgate of Welfare Reform: Elements for a Socioanthropological Critique. Current Anthropology, 55 (S9): 138-46.

Dubois, V. (2019). Institutional Order, Interaction Order and Social Order: Administering Welfare, Disciplining the Poor. Politiche sociali/Social Policies, 3: 507-520. 
Foucault, M. (2002). The Subject and Power in Essential Works of Foucault 1954-1984. London: Penguin.

Freyssinet, J. (2000). Plein emploi, droit au travail, emploi convenable, Revue de l'IRES, 34(3): 1-32.

Gautié, J. (2002), De l'invention du chômage à sa deconstruction. Genèses, 46: 60-76.

Graziano, P., Jacquot, S., Palier, B. (eds.) (2011). The EU and the Domestic Politics of Welfare State Reforms. Basingstoke: Palgrave Macmillan.

Guitton, C. (1994). Le chômage entre question sociale et question pénale en France au tournant du siècle. In: Aux sources du chômage. 1880-1914. Mansfield, M., Salais, R., Whiteside, N. (eds.). Paris: Belin: 63-89.

Hassenteufel, P. et al. (1999). L'émergence d’une »élite du welfare«? Sociologie des sommets de l'État en interaction. Le cas des politiques de protection maladie et en matière de prestations familiales (1981-1997). Rennes: CRAPS-MIRE.

Kröger, S. (2009). The Open Method of Coordination: Underconceptualisation, overdetermination, de-politicisation and beyond. In: What we have learnt: Advances, pitfalls and remaining questions in OMC research, Kröger, S. (ed.). European Integration online Papers, 1(13), http:// eiop.or.at/eiop/texte/2009-005a.htm

Lahire, B. (1999). L'invention de l'»illettrisme«. Rhétorique publique, éthique et stigmates. Paris: La Découverte.

Lebaron, F. (2001). Chômage, précarité, pauvreté. Quelques remarques sur la définition sociale des objectifs de politique économique. Regards Sociologiques, 21: 67-78.

Lødemel, I., Moreira, A. (eds.) (2014). Activation or Workfare? Governance and the Neo-Liberal Convergence. New York: Oxford University Press.

Marimbert, J. (2004). Rapport au ministre des Affaires sociales, du travail et de la solidarité sur le rapprochement des services de l'emploi. Paris: Ministère des Affaires sociales, du Travail et de la Solidarité.

Maruani, M. (2002). Les mécomptes du chômage. Paris: Bayard.

McBride, S., Williams, R.A. (2001). Globalization, the Restructuring of Labour Markets and Policy Convergence. The OECD 'Jobs Strategy'. Global Social Policy, 1(3): 281-309.

Mathiot, P. (2001). Acteurs et politiques de l'emploi en France 1981-1993. Paris: L'Harmattan.

OECD (various dates). Employment Outlook. Paris: OECD.

Orwell, G. (1989). The road to Wigan Pier. London: Penguin.

Page, E.P., Mark-Lawson, J. (2007). Outward-Looking Policy Making. In: Making Policy in Theory and Practice, Bochel, H., Duncan, S. (eds.). Bristol: Policy Press: 47-63.

Radaelli, C. (2003). The Europeanization of Public Policy. In: The Politics of Europeanization, Featherstone, K., Radaelli, C. (eds.). Oxford University Press: 27-56.

Salais, R., Baverez, N., Reynaud, B. (1986). L'invention du chômage. Paris: Presses universitaires de France.

Sztandar-Sztanderska, K. (2016). Obywatel spotyka Państwo. O urzędach pracy jako biurokracji pierwszego kontaktu. Warszawa: Wydawnictwo Naukowe Scholar.

Topalov, C. (1994). Naissance du chômeur, 1880-1910. Paris: Albin Michel. 
Weber, M. (2011). The Protestant Ethic and the Spirit of Capitalism. New York: Oxford University Press.

Acknowledgments: This paper received support from the Maison des Sciences de l'Homme d'Alsace (MISHA) and the Excellence Initiative of the University of Strasbourg. Previous versions have been published in French and Portuguese (État social actif et contrôle des chômeurs, Politiques Européennes, 21, 2007; Estado Social Activo e Controlo dos Desempregados, Sociologia, 17/18, 2007/2008). I would like to thank Emmanuel Kobena-Kuto, who prepared a first English version, and Jean-Yves Bart for his linguistic revisions. I would also like to thank the anonymous reviewers for their comments, and Andrzej Zybała for his help in the publication process. 